\title{
Fashion: Akumulasi Modal dan Habituasi Pada Praktik Dakwah Komunitas Hijrah
}

\author{
Wisnu Pudji Pawestri ${ }^{*}$, Siti Kholifah ${ }^{2}$ \\ 1 Universitas Brawijaya, Indonesia; tyaspawestri94@gmail.com \\ 2 Universitas Brawijaya, Indonesia; ifah_sosio@ub.ac.id \\ * Correspondence
}

Received: 2020-05-29; Accepted: 2020-07-15; Published: 2020-08-29.

\begin{abstract}
The diversity of religious practices forms a new pattern, where each community is challenged to be 'in tune' with the current trend and situation. The pattern challenges each community to compete with others to provide good bargaining power so the audience is in the discourse that they produced. To propagate hijrah discourse, Taubah Muslim (Community's name is disguised) community uses fashion as a strategy in da'wah activism. Taubah Muslim hijrah community is a community that persuades millennials to hijrah through da'wah. Fashion in this context is positioned as a medium as well as a 'new way' to approach the da'wah target. This article puts fashion as a social practice in which there are forms of representation and expression of Islamic values. Using a descriptive qualitative method, this article highlights how fashion is used and chosen by agents in da'wah arena as a strategy to reproduce hijrah discourse. Based on Pierre Bourdieu's social practice theory, the results of the analysis conclude that fashion is used as a placement strategy to encourage perceptions of shared identity. Furthermore, fashion functionally is used as an acculturation technique to approach the da'wah target (young generation). The choice of fashion as a da'wah strategy is based on habitus and capital owned by agents in the da'wah arena. Then, Fashion is treated as a representation of other meanings that are presented by agents to create reality, which is based on their habitus and capital. The existence of capital becomes an important thing for the community to maintain, strengthen, and differentiate (distinction) with others in achieving a dominant position, namely in terms of propagative hijrah discourse.
\end{abstract}

Keywords: Capital; Da'wah; Fashion; Habitus; Social Practice.

Abstrak: Keragaman praktik beragama membentuk sebuah pola baru, di mana setiap komunitas dituntut untuk 'seirama' dengan tren yang sedang berlaku. Pola tersebut mengajak setiap komunitas untuk berlomba saling memberikan daya tawar yang menarik agar audiens berada pada wacana yang sedang mereka usung. Untuk menyebarluaskan wacana hijrah, komunitas hijrah Taubah Muslim (nama komunitas disamarkan) menggunakan fashion sebagai strategi dalam aktivisme dakwah. Komunitas hijrah TM adalah komunitas yang mengajak milenial untuk berhijrah melalui dakwah. Fashion pada konteks ini diposisikan sebagai medium sekaligus jalan baru untuk mendekatkan diri kepada target dakwah. Artikel ini memposisikan fashion sebagai praktik sosial yang di dalamnya terdapat bentuk representasi dan ekspresi nilai-nilai Islam. Melalui pendekatan kualitatif deskriptif, artikel ini menyoroti bagaimana fashion digunakan dan dipilih oleh agen dalam arena pergulatan dakwah sebagai strategi yang tepat untuk mereproduksi wacana hijrah. Melalui teori praktik sosial Pierre Bourdieu, hasil analisis menyimpulkan bahwa fashion digunakan sebagai strategi penempatan diri untuk menggiring persepsi atas kesamaan identitas. Selanjutnya, fashion secara fungsional juga digunakan sebagai teknik akulturasi untuk mendekatkan diri dengan target dakwah (generasi muda). Pemilihan fashion sebagai strategi dakwah, didasarkan atas habitus dan modal yang dimiliki oleh agen dalam arena dakwah. Fashion kemudian diposisikan sebagai representasi atas makna-makna lain yang dihadirkan agen untuk menciptakan realitas, yang bersumber pada habitus dan modal mereka. Keberadaan modal menjadi sesuatu yang penting bagi komunitas untuk mempertahankan, memperkuat, dan membedakan (distinction) komunitasnya dengan yang lain dalam meraih posisi yang dominan, yaitu dalam hal penyebarluasan wacana hijrah.

Keywords: Dakwah; Fashion; Habitus; Modal; Praktik Sosial. 


\section{Pendahuluan}

Hijrah dapat dikatakan sebagai praktik baru oleh Muslim di Indonesia dalam mengekspresikan nilai keislamannya dan menjadi cukup populer saat ini. Hijrah sebagai fenomena kontemporer, tidak lagi dimaknai sebagai perpindahan Nabi dari Mekkah ke Madinah (Masud, 1990), melainkan telah menjadi tren baru yang dimaknai sebagai perubahan gaya hidup untuk sesuai dengan anjuran Islam. Dalam lingkup Nasional di Indonesia, praktik hijrah tidak dapat sepenuhnya padu dan koheren karena keragaman kelompok yang muncul yang mengatasnamakan gerakannya sebagai 'hijrah'. Ada kelompok yang menekankan hijrah dengan meninggalkan riba seperti yang dilakukan Komunitas Tanpa Riba (KTR); ada kelompok Hijrah yang fokusnya meninggalkan hubungan lawan jenis sebelum menikah seperti Indonesia Tanpa Pacaran (ITP); ada pula kelompok hijrah yang fokus untuk menutup aurat dengan berbusana muslim seperti Hijab Squad. Keragaman kelompok yang bergerak mengatasnamakan 'hijrah' ini menjadikan praktik Hijrah sebagai payung yang mewadahi beragam ekspresi, nilai, dan figur. Riset Daoud Casewit (1998) mengungkapkan bahwa pemaknaan atas hijrah terbagi menjadi dua jenis, yaitu hijrah sebagai peristiwa historis dan hijrah sebagai sebuah metafora, artinya konsepsi terkait hijrah belum final dan masih terbuka sebagai arena kontestasi pemaknaan. Sehingga praktik hijrah merupakan bentuk rangkaian peristiwa historis yang dimaknai oleh individu dan kemudian direpresentasikan melalui bahasa dan simbol. Pada taraf tertentu hijrah bukan lagi dipandang sebagai perilaku spiritual antara subjek dengan Tuhannya, melainkan telah menjadi sebuah praktik kebudayaan untuk berbagai praktik representasi, bahasa, dan pertukaran makna.

Tidak hanya keragaman kelompok, hijrah sebagai konsep baru terkait pengekspresian kesalehan sosial pun juga memberikan dampak pada presentasi diri setiap muslim. Hal tersebut tampak dari perubahan penampilan individu yang berhijrah seperti berjilbab lebar dan panjang (wanita), berjenggot dan bercelana cingkrang (pria) (Nuroniyah, 2019). Praktik hijrah yang menjadi tren baru ini merupakan salah satu bagian dari proses Islamisasi dengan tujuan menciptakan budaya islami yang sesuai dengan syariat Islam (Van Bruinessen, 2002). Hijrah merupakan aktivisme baru yang bertujuan untuk menyiarkan tuntunan menuju kebaikan yang dilandaskan pada syariat Islam. Acuan cara hidup yang berlandas pada syariat Islam menjadi sebuah standarisasi dalam praktik keberagamaan. Syariat Islam kemudian menjadi sistem pengaturan bagi gaya hidup Muslim untuk terus mempraktikkan kebaikan. Maka ulasan tersebut mengasumsikan bahwa hijrah menjadi identik dengan terminologi 'berubah menjadi lebih baik dari sebelumnya'.

Praktik hijrah terus dikampanyekan melalui gerakan dakwah. Khalid Masud mengatakan bahwa aktivisme dakwah menjadi semakin terlihat setelah pembentukan rezim Orde Baru yang dipimpin oleh mantan Presiden Soeharto pada pertengahan 1960-an dan semakin mencolok selama abad kedua puluh (Masud, 1995). Praktik ini terlihat dari banyaknya film, sinetron, musik, media cetak dan media online condong ke arah kepentingan agama dan lebih banyak wanita yang mengenakan jilbab (Barendregt, 2011; Rakhmani, 2017). Semakin banyak pengkhotbah Islam muncul, baik di media lama seperti televisi dan radio, hingga media baru. Pengikut mereka secara aktif mengambil bagian dalam kegiatan dakwah ini dan berpartisipasi dalam kelompok studi atau pengajian Qur'an baik secara online dan offline (Hew, 2018; Husein \& Slama, 2018). Ini kemudian membuat aktivitas dakwah menjadi semakin masif dan mudah untuk dijangkau. Hal tersebut menunjukkan bahwa percepatan perkembangan teknologi komunikasi saat ini telah membawa masyarakat pada sebuah tatanan jarak dan waktu yang tidak lagi menjadi permasalahan untuk berkomunikasi (Singhal, Rogers, \& Brown, 1993). Sehingga teknologi digital menjadi alat alternatif dalam merepetisi wacana. Tentunya hal ini juga berkaitan dengan perubahan pola keberagamaan. Perubahan pola keberagamaan atas praktik beragama yang kini hadir baik melalui daring dan luring pada dasarnya tidak serta merta menggantikan pola yang ada sebelumnya. Melainkan kehadiran media digital justru memberikan pola baru bagi muslim dalam beragama (Al-Zaman, 2020; Campbell, 2010). Dengan kata lain, praktik baru, memunculkan pola baru. Artinya perubahan pola keberagamaan disebabkan oleh ragam praktik yang muncul, yang kemudian didukung dengan variasi medium serta wacana.

Kemudian, perubahan praktik keberagamaan memunculkan adanya persaingan antar organisasi dan komunitas muslim (Meuleman, 2011) dalam menciptakan 'daya tawar baru' untuk merekrut 
massa. Hal tersebut menuntut kreativitas dari tiap komunitas hijrah untuk saling berlomba mendapatkan ruang dan eksistensi di masyarakat. Penyampai pesan dituntut untuk pandai dalam menghias, meramu, dan mengemas pesan agar lebih mudah diterima oleh masyarakat. Respon atas hal tersebut dapat dilihat dengan berbagai strategi dakwah yang dilakukan muslim mulai dari strategi dalam bermedia sosial, strategi kampanye gaya hidup Islami termasuk cara berpakaian (Hew, 2018).

Perubahan praktik keberagamaan kemudian juga berdampak pada komodifikasi pesan dan komodifikasi bentuk dakwah. Komodifikasi dakwah tercermin dalam keberagaman gaya dakwah yang muncul. Meskipun mereka memiliki keseragaman dalam hal acuan hidup karena standar-standar yang merujuk pada syariat Islam, namun pada praktiknya terdapat keberagaman dalam pola keberagamaan. Sehingga representasi atas keberagamaan tersebut dipraktikkan dalam banyak cara melalui banyak medium. Misalnya melalui fashion, dan pengekspresian simbol Islam yang erat hubungannya dengan gaya hidup. Ubay sebagai salah satu informan mengungkapkan bahwa,

Komunitas ini memang berdakwah tidak hanya melalui ceramah. Saat ini kita harus lebih jauh memanfaatkan yang ada. Misal dengan memanfaatkan baju kita. Oh kalau memakai kerudung berarti seorang muslim, oh kalau memakai busana muslim berarti dia muslim. Jadi dengan menunjukkan simbol Islam, adalah bentuk pengagungan kita kepada Islam. Dan itu merupakan dakwah. (Ubay, Malang, wawancara personal, 24 Juni 2020)

Seperti halnya juga yang ditemukan oleh Fakhuroji dan Umi Rojiati (2017) dalam risetnya, yang meneliti tentang praktik beragama kalangan Muslimah urban melalui komunitas Hijaber Bandung sebagai instrumen dalam pembentukan identitas. Pernyataan Ubay yang kemudian juga didukung dengan hasil riset Fakhuroji dan Umi menunjukkan bahwa di era kontemporer, komunitas Muslim yang mengatasnamakan 'hijrah' mempergunakan fashion dan simbol lain sebagai medium untuk berdakwah sekaligus berekspresi. Pengekspresian praktik beragama yang diartikulasikan melalui fashion kemudian juga membentuk identitas Muslim. Pada konteks yang lebih luas, dapat dikatakan bahwa keberagaman pola keberagamaan berkaitan dengan keberagaman medium yang dipilih sebagai instrumen dalam pembentukan identitas sekaligus menjadi komunikasi simbolik yang merepresentasikan ideologi, identitas, afiliasi komunitas, serta status sosial.

Perspektif yang berbeda juga ditemukan dalam tulisan Siti Kholifah (2014). Pada artikelnya yang berjudul Gendered Continuity and Change in Javanese Pesantren, Siti Kholifah mengungkapkan bahwa pakaian merupakan salah satu cara merepresentasikan identitas dan nilai agama dan budaya, serta menjadi simbol status, kelas, kekuasaan dan gender. Tradisi berpakaian tidak hanya menggambarkan jejaring genealogis yang melestarikan tradisi kuno, tetapi juga menjelaskan keterkaitan dengan masyarakat luar, dan dengan institusi yang memiliki kekuatan untuk menanamkan nilai-nilai atau ideologi mereka. Seperti halnya tradisi berpakaian pesantren juga dipengaruhi oleh budaya lain yang dianggap berperan sebagai penyebaran Islam, misalnya, budaya Islam dari India (Gujarat, Coromandel), Cina Selatan, Arab, Mesir dan Persia mempengaruhi Indonesia. Penelitian ini memberikan sebuah perspektif baru bahwa pakaian merupakan ungkapan/ekspresi yang diartikulasikan dari dialog antara tradisi lokal dengan budaya luar yang kemudian menjadi representasi atas nilai budaya dan identitas dalam suatu era. Artinya pakaian merupakan perilaku budaya yang bersentuhan dengan ruang dan waktu, ia akan terus mengalami perubahan, penyesuaian, dan selalu berinteraksi dengan nilai-nilai.

Perspektif lainnya ditemukan dalam tulisan Carla Jones (2007). Artikel ini mengemukakan bahwa kebangkitan fashion sebagai pakaian dan medium ekspresi beragama juga harus dipahami dalam konteks perdebatan nasional tentang modernitas dan kesalehan. Melalui pertimbangan fashion sebagai komoditas, Carla berpendapat bahwa komodifikasi busana Islami di perkotaan Indonesia bukanlah proses yang lugas, melainkan sebagai ajang bagi umat Islam Indonesia untuk memikirkan hubungan antara keimanan, gender, dan materialitas. Artikel ini memberikan perspektif baru bahwa pemanfaatan fashion sebagai medium untuk penyebarluasan praktik hijrah pada dasarnya juga memiliki keterkaitan yang erat dengan ranah makro, yaitu bentuk kompromi antara modernitas dan kesalehan. Ariel Heryanto (2015) menyebutkan agama dan modernitas bukan hanya saling terkait, melainkan juga bersekutu hingga mampu mendukung kegiatan-kegiatan kolektif yang berjangka 
panjang. Maka, fashion sebagai ekspresi keberagamaan merupakan hasil kompromi komunitas Muslim dengan modernitas.

Sejalan dengan studi-studi tersebut, artikel ini berasumsi bahwa strategi yang dibentuk oleh pendakwah tentunya tidak muncul secara tiba-tiba melainkan melalui struktur kognitif dan subjektif dari agen. Strategi dakwah di masa silam akan berbeda dengan strategi dakwah saat ini, begitu pula strategi pendakwah satu juga berbeda dengan pendakwah yang lain. Perbedaan strategi tersebut digerakkan sesuai dengan modal serta habitus yang dimiliki di dalam arena dari waktu ke waktu mengingat strategi dapat berubah seiring dengan perubahan struktur sosial masyarakat. Seperti yang dipraktikkan oleh salah satu komunitas hijrah di Kota Malang, yaitu komunitas Taubah Muslimat (nama sebenarnya disamarkan, dan dalam artikel ini selanjutnya disebut komunitas TM). Komunitas ini memiliki gerakan untuk mengajak muslim berhijrah. Penyebarluasan wacana hijrah tersebut dikampanyekan melalui gerakan dakwah. Mereka berdakwah di beberapa kafe, pusat perbelanjaan, taman, dan tempat wisata. Mereka memilih menggunakan gaya berpakaian yang kasual dan fashionable ketika berdakwah di depan anak muda, namun, akan mengubah gaya berpakaiannya dengan menggunakan jubah/gamis dan serban ketika berdakwah di depan generasi tua (Kurnia, wawancara personal, 10 Januari 2020). Hal ini memicu argumen bahwasannya fashion menjadi medium bagi komunitas hijrah dalam usaha penyebarluasan wacana hijrah. Fashion yang erat kaitannya dengan gaya hidup, justru menjadi cara baru bagi mereka untuk mengatur dan mengkampanyekan gaya hidup baru sesuai dengan Islam. Artinya, pengorganisasian tersebut justru dilakukan melalui tren gaya hidup yang akhirnya juga melahirkan gaya hidup baru.

Di sisi lain, pada prinsipnya pakaian biasanya dikaitkan dengan suatu keberfungsian, seperti penutup untuk perlindungan, atau sebagai perhiasan untuk ekspresi dan daya Tarik (Flugel, 1930). Tetapi dibalik keberfungsian tersebut, pakaian (fashion) juga memiliki peran. Pada konteks di atas, penggunaan pakaian berperan sebagai simbol untuk mengkomunikasikan bahwa 'saya' memiliki kesamaan identitas dengan 'anda' melalui gaya penampilan yang sama. Fashion tidak lagi didefinisikan melalui tipe dan hubungan yang representatif, tetapi melalui ekspresi yang diciptakan oleh tubuh dan pakaian yang mengonseptualisasikan perwujudan interaktif sebagai proses bergerak dan berpikir (Kozel, 2008). Fashion merupakan bentuk improvisasi berpakaian yang dilandaskan sebagai medium untuk menegosiasikan diri terhadap individu lain melalui cara berpakaian. Memahami fashion sebagai praktik penempatan tubuh, pada akhirnya juga menumbuhkan perspektif baru tentang pergeseran makna fashion sebagai pakaian (objek), menjadi fashion sebagai praktik berpakaian (aktivitas) yang menghubungkan tubuh dan lainnya melalui interaksi (Berglin et al., 2006). Praktik berpakaian yang dilakukan oleh komunitas TM tidak hanya bertujuan untuk terlihat fashionable, melainkan jauh di balik itu ia mempergunakan peran pakaian untuk menanamkan sisi-sisi idelogisnya dengan harapan bahwa pesan dakwah dapat mengubah gaya hidup serta perilaku sosial yang sesuai dengan Islam. Dengan begitu, fashion merupakan strategi yang dilekatkan dengan presentasi diri untuk tujuan-tujuan tertentu.

Praktik ini pada dasarnya muncul karena agen berusaha menyesuaikan tindakannya dengan ranah. Dalam suatu arena terdapat berbagai strategi yang dimainkan untuk menjadikannya dominan di antara agen yang lain. Sama halnya dengan komunitas TM, praktik sosial yang dilakukan untuk menjadi dominan adalah dengan memilih fashion sebagai strategi dakwah untuk menyebarluaskan wacana hijrah. Menariknya, komunitas TM tidak sekedar memosisikan pakaian sebagai objek, melainkan mereka mempergunakan peran sosial dari pakaian dalam aktivisme dakwah untuk menjadi pembeda dan dominan. Hal ini tentunya juga melibatkan faktor-faktor yang lain. Dalam gagasan Bourdieu, praktik sosial muncul dari hasil interaksi antara habitus dan ranah (Bourdieu, 1977). Habitus bisa didefinisikan sebagai struktur kognitif yang menghubungkan seorang agen melakukan praktik sosial tertentu sehingga menjadi suatu kebiasaan yang tidak dipertanyakan lagi. Hal tersebut kemudian bertahan lama, terus berkembang sesuai dengan konteks yang terjadi sekarang dan membentuk perilaku serta menjadi produk dari kepribadian dan sejarah agen. Habitus menghasilkan praktik- praktik yang kemudian menjadi prinsip strategi yang memungkinkan agen mengatasi situasi yang tidak terduga dan penuh ketidakpastian. 
Salah satu tujuan utama tulisan Pierre Bourdieu adalah untuk mengatasi dualisme antara objektivisme dan subjektivisme. Sebagai bagian dari 'teori praktik yang lebih luas,' Bourdieu terkenal mengembangkan konsep habitus untuk mengatasi kebuntuan objektivisme dan subjektivisme ini (Huang, 2019). Bourdieu mengkonsepsikan habitus sebagai nilai sosial atau norma yang dijalani oleh manusia dan diciptakan melalui proses sosialisasi nilai yang berlangsung lama. Proses tersebut kemudian mengendap dan bertahan menjadi cara berpikir serta pola perilaku. Konsep habitus Bourdieu memungkinkan untuk menyanggah teori ekonomisme Marx (Desan, 2014). Tindakan bukan hanya didorong oleh kepentingan ekonomi, melainkan terdapat disposisi dari dalam sehingga individu bukan hanya aktor sosial, namun lebih merupakan agen (yang digerakkan dari dalam) dan bertindak ke luar. Terdapat struktur logis praktik yang tidak berasal dari perhitungan sistematis yang secara sadar dibuat dan bukan merupakan bentuk penentuan tindakan dari eksternal pelaku, tetapi dari habitus pelaku yang kemudian menggerakkan struktur-struktur tersebut. Bourdieu menganggap bahwa habitus seseorang berkaitan erat dengan praktik yang dilakukan. Keterkaitan tersebut dijelaskan melalui serangkaian disposisi yang dimiliki oleh agen dalam pola pengasuhan dan pendidikan. Habitus menjadi hasil keterampilan atas tindakan praktis (tidak harus selalu disadari) yang kemudian diterjemahkan menjadi suatu kemampuan yang kelihatannya alamiah dan berkembang dalam lingkungan sosial tertentu. Habitus menjadi dasar kepribadian individu sekaligus penghasil praktik-praktik kehidupan yang sesuai dengan struktur-struktur obyektif.

Penelitian ini berusaha meletakkan konsep habitus dalam fenomena aktivisme beragama. Kerangka yang dimiliki oleh Bourdieu dianggap dapat membongkar keterkaitan antara agen dalam komunitas dengan praktik-praktik yang dioperasikan. Habitus yang dimiliki agen dalam komunitas menghasilkan keberagaman praktik beragama saat ini. Dalam sudut pandang studi ini, keberagaman praktik beragama di era kontemporer tidak hanya digerakkan dari kondisi struktur objektif dari luar melainkan juga digerakkan dari dalam atas dialektika antara objektivisme dan subjektivisme. Inilah yang pada dasarnya dikritik oleh Bourdieu atas pemikiran Marx. Teori Marx hanya mendefinisikan posisi sosial dengan mengacu pada satu posisi dalam hubungan-hubungan produksi ekonomi dan mengabaikan hubungan-hubungan produksi budaya. Dengan demikian, strategi dominasi pada dasarnya sangat beragam tergantung pada jenis arenanya.

Maka, tulisan ini pada prinsipnya adalah usaha kritis untuk memahami bagaimana praktik sosial tersebut muncul dan beroperasi. Tulisan ini berusaha membedah bagaimana fashion digunakan secara sosial dan dipilih oleh agen sebagai strategi yang tepat untuk penyebarluasan wacana hijrah dalam arena pergulatan dakwah. Untuk menjawab pertanyaan penelitian, peneliti menggunakan metode kualitatif deskriptif, dengan teknik pengambilan data melalui observasi partisipan, dan wawancara. Artikel ini ditulis dengan menggunakan kerangka teoritis dari Pierre Bourdieu dalam teori Praktik Sosial. Teori Bourdieu dipilih karena penulis menganggap konsep Bourdieu mengenai dunia sosial mampu menjelaskan proses-proses yang dilalui untuk menciptakan dunia sosial ataupun perilaku manusia dalam bertindak yang secara tidak sadar dilakukan, termasuk pada konteks ini yaitu terkait dengan praktik beragama melalui penggunaan fashion sebagai medium untuk penyebarluasan wacana hijrah yang dilakukan dalam gerakan dakwah.

\section{Hasil dan Pembahasan}

Untuk memudahkan penjelasan hasil dan pembahasan, penulis terlebih dahulu akan mendeskripsikan gambaran secara umum subjek penelitian. Dalam sub bab ini, penulis akan mendeskripsikan bagaimana gerakan dakwah dipraktikkan oleh komunitas hijrah TM. Pada bagian berikutnya, penulis akan mengeksplorasi peran fashion sebagai sebuah strategi, dan bagian akhir akan menjelaskan bagaimana fashion digunakan sebagai strategi dakwah dan mengapa praktik tersebut muncul. Dalam bab ini penulis berusaha untuk mendialogkan antara fakta sosial yang terjadi dengan kerangka teori Praktik Sosial dari Pierre Bourdieu. 


\section{Gerakan Dakwah Komunitas Hijrah TM}

Komunitas TM merupakan salah satu kelompok hijrah di Kota Malang yang memiliki gerakan mengajak generasi milenial dan pelaku industri ekonomi kreatif untuk berhijrah. Asrul menjelaskan bahwa gerakan ini sebagai upaya untuk memperjuangkan Islam (Asrul, wawancara personal, 26 September 2020). Asal usul istilah ini sebenarnya digunakan untuk menjelaskan migrasi secara fisik nabi Muhammad dari Mekah ke Madinah pada $622 \mathrm{M}$ dan juga migrasi sekelompok Muslim dari Mekah ke Abyssinia pada 615-622 M (Masud, 1990). Namun, kini hijrah justru dimaknai dalam kerangka konseptual yang berbeda. Saat ini hijrah lebih merujuk pada perpindahan sikap keagamaan. Berpindah dari sikap beragama yang kasual menjadi lebih ketat dalam mengamalkan hukum-hukum Islam. Sedangkan dakwah dapat diartikan sebagai upaya terorganisir untuk memperkuat dan memperdalam kesalehan umat Islam dalam membantu mereka menjalani kehidupan sehari-hari sesuai dengan prinsip-prinsip Islam (Meuleman, 2011). Kedua terminologi tersebut memberikan gambaran bahwa gerakan dakwah dan gerakan hijrah pada konteks ini tidak dapat dipisahkan. Hijrah diposisikan sebagai representasi atas sebuah pemaknaan terhadap wacana hijrah. Sedangkan dakwah sendiri merupakan medium pengekspresian sekaligus bahasa yang digunakan untuk mengekspresikan wacana tersebut. Jadi medium atas ajakan tersebut adalah dakwah. Komunitas TM melakukan dakwah di kafe-kafe, beberapa pusat perbelanjaan, dan tempat-tempat wisata. Alasannya, dakwah dengan cara seperti ini cukup bisa menarik perhatian khalayak, khususnya bagi kalangan muslim yang enggan untuk datang ke masjid. Strategi dakwah yang tidak hanya dilakukan di masjid dianggap efektif untuk menjangkau massa, terutama bagi segmentasi utama mereka. Hal ini sebenarnya juga didasarkan pada visi mereka yaitu sebagai 'jembatan' kalangan muslim dari kehidupan yang gelap ke terang.

Sasaran utama dakwah mereka adalah kalangan muda milenial yang awam terhadap pengetahuan Islam. Sasaran ini mereka sebut dengan istilah 'ring 3 (tiga)' atau dengan sebutan lain yaitu kelompok 50:50 acception, artinya kalangan muslim yang berpeluang untuk diajak hijrah dengan perbandingan $50 \%$ untuk menerima dan 50\% sisanya menolak. Biasanya kelompok ini diidentikkan dengan anak muda yang belum berhijrah, namun telah memiliki keinginan untuk hijrah. Ring tiga diklasifikasikan dan diidentikkan dengan ciri-ciri seperti, tidak memakai kerudung/jilbab, merokok, bertato, bertindik (bagi pria). Untuk menjangkau ring tiga, mereka memberlakukan sebuah aturan tidak tertulis terkait adab berpakaian. Aturan tesebut diberlakukan bagi pengurus inti yang terlibat secara langsung dalam aktivitas dakwah. Aturannya adalah dengan berpakaian kasual, modis, dan jauh dari kesan kaku seperti tidak memakai jubah/gamis, tidak memakai sarung, dan tidak memakai serban. Namun, hal ini akan berbeda ketika mereka berdakwah dihadapan muslim generasi tua yang mereka anggap paham tentang pengetahuan, dan syariat-syariat islam. Mereka akan berpakaian sebaliknya, yaitu memakai jubah, gamis, berkerudung syar'i, hingga memakai kurfiyah dan serban (Kurnia, wawancara personal, 10 Januari 2020). Namun pada dasarnya terdapat prinsip utama yang tidak dapat dilanggar oleh mereka, yaitu bercelana cingkrang dan berjenggot (bagi pria), dan tidak mengenakan pakaian (serta hijab) berwarna mencolok (bagi wanita). Bagi mereka, prinsip tersebut merupakan simbol yang mewakili identitasnya sebagai Muslim serta bentuk pengagungan terhadap Islam.

Komunitas hijrah TM beranggotakan sekitar 175 orang yang kebanyakan berusia di antara 23 hingga 40 tahun. Mayoritas dari mereka adalah seorang pengusaha mandiri dan pelaku industri UMKM (Usaha Mikro Kecil Menengah). Hijrah bagi setiap anggota merupakan sebuah perjalanan hidup, sebuah hidayah sekaligus kesempatan untuk 'membuang' sejarah masa lalu yang kelam. Hijrah menjadi sebuah jalan yang menuntun mereka menuju perbaikan diri. Menjadi sangat logis ketika setiap individu dalam komunitas memiliki 'periode kesejarahan hidup', yaitu ia sebelum berhijrah dan ia setelah berhijrah. Dua periode kesejarahan tersebut memiliki pengaruh pada struktur kognitif mereka yang menentukan bagaimana mereka bertindak dan menciptakan realitas sosial di tengah arena dakwah yang semakin masif termasuk pada strategi-strategi yang dilakukan untuk menyaingi komunitas lain dalam konteks dakwah. 


\section{Peran Fashion sebagai Strategi}

Secara sosial, praktik hijrah yang dilakukan komunitas TM mengacu pada momentum hijrah yang dilakukan oleh Nabi. Momentum tersebut direpresentasikan melalui pemaknaan-pemaknaan baru yang didasarkan dengan pengalaman hidup individu. Hijrah pada akhirnya memiliki banyak makna bagi setiap individu dalam komunitas, dan kemudian dibahasakan melalui berbagai representasi termasuk gerakan dakwah. Gerakan dakwah merupakan bahasa yang digunakan oleh komunitas untuk mewakili pemaknaan individu mereka terkait hijrah. Tentunya, untuk mendistribusikan ideologi dan makna tersebut, mereka membutuhkan strategi dakwah yang tepat melalui berbagai cara. Hal ini dikonfirmasi oleh Asrul dalam sebuah wawancara bahwa,

Setiap orang pada awalnya bisa saja memaknai hijrah secara berbeda-beda. Sampai ketika dia memahami sebagaimana ilmu dan amalan hijrah seperti yang diajarkan Nabi dan para sahabat. Maka pemahaman itu yang akan meluruskan makna seseorang atas hijrah serta menetapkan tujuannya. Begitu pula di TM, karena kami semua pernah dalam dunia yang gelap maka kami memilih strateginya yang bisa lebih diterima oleh mereka yang masih tersesat. (Asrul, wawancara personal, 26 September 2020)

Cara-cara tersebut dimanifestasikan melalui pemilihan pakaian dalam berdakwah. Komunitas ini beranggapan bahwa pakaian merupakan layer terluar yang dinilai strategis bagi mereka untuk merangkul kelompok-kelompok yang dianggapnya belum sesuai dengan prinsip Islam. Pakaian seolah bukan hanya terkait kebendaan ataupun objek materiil yang digunakan untuk melindungi kulit, melainkan pakaian dalam sudut pandang komunitas ini juga merupakan sebuah makna simbolik yang digunakan sebagai medium atas ideologi dan representasi makna terkait hijrah.

...strategi ini memang sengaja kami lakukan karna secara tidak langsung pakaian itu menyimbolkan posisi hijrah kita yang bagaimana. Hijrah kita kan bukan hijrah yang kaku seperti pada umumnya. Tapi kita lebih ke arah yang santai. Tujuannya agar anak muda itu lebih nyaman. (Kurnia, wawancara personal, 10 Januari 2020)

Strategi pemilihan pakaian ini dilakukan untuk mensimbolkan bahwa hijrah tidak harus dilakukan secara kaku dan literal dengan pakaian yang terkesan sangat 'islami', melainkan mereka ingin menyimbolkan bahwa hijrah itu santai, luwes dan suatu proses yang mudah untuk dijalani. Maka disinilah fashion berperan. Strategi berpakaian saat berdakwah seolah menjadi perwakilan makna, bahwasannya melalui kesamaan gaya penampilan menunjukkan bahwa kita memungkinkan untuk berada pada kelompok dan pemikiran yang sama. Dan memungkinkan untuk mengubah stigma atau identitas kita bagi orang lain (Kawamura, 2005). Pakaian menjadi umpan yang dianggap mampu untuk menegaskan identitas beserta wacana yang diusung.

Untuk itu, pakaian dalam konteks ini merupakan sebuah simbol atas sebuah pemaknaan yang lebih luas. Ibarat kata, pakaian hanyalah sebuah 'kulit' yang digunakan sebagai alat untuk tujuan yang lebih besar, yaitu penegasan identitas dan medium dakwah. Fashion bagi komunitas TM merupakan teknik pengaturan tubuh yang digunakan sebagai alat untuk mengkonstruksi identitas sehingga memunculkan kesamaan dengan orang lain (Craik, 2009). Fashion adalah praktik budaya yang terikat dengan identitas diri kita baik sebagai individu ataupun sebagai anggota dari suatu kelompok (Aspers \& Godart, 2013). Artinya ketika berbicara terkait identitas, maka juga berbicara terkait pemosisian diri dalam kehidupan sosial (Cohen, 1985; King, 1991). Seperti yang terjadi di komunitas TM, mereka telah mengidentifikasi bahwa masyarakat cenderung 'anti' terhadap kajian-kajian dakwah yang diberikan oleh kelompok hijrah karena stigma buruk terhadap mereka. Maka untuk mengatasinya, mereka memposisikan diri menjadi muslim yang modern dan inklusif melalui penggunaan pakaian yang terkesan santai dan modis dengan mengikuti tren fashion saat ini (Kurnia, wawancara personal, 10 Januari 2020). Pernyataan ini kemudian juga diperkuat oleh Asrul, "ya memang kita tahu sendiri bahwa masyarakat kalau melihat orang yang pakaiannya sangat islam gitu ya, pakai gamis, serban, itu nanti dikira teroris. Maka dari itu kita sesuaikan pakaian sesuai dengan segmen dakwah kita, yaitu ring 3 yang kebanyakan adalah anak muda. Kita sesuaikan itu" (Asrul, wawancara personal, 26 September 2020). Gambar berikut mendeskripsikan secara lebih jelas dan terperinci terkait dengan pakaian yang dipilih pada setiap kajian dakwah. Gambar 1 memperlihatkan gaya berpakaian untuk laki-laki, dengan memakai celana 
panjang selutut dan memakai kaos. Gambar 2 memperlihatkan gaya pakaian perempuan dengan pakaian yang kasual namun tetap menutup aurat. Kedua gambar menunjukkan bahwa mereka berpakaian sesuai dengan segmen dakwahnya namun tanpa harus mereduksi simbol Agama yang ditampilkan sesuai dengan anjuran Islam, seperti celana panjang selutut (pria), dan berjilbab (wanita). Hal ini kemudian juga menjadi bentuk penegasan simbol atas identitas mereka sebagai seorang muslim.

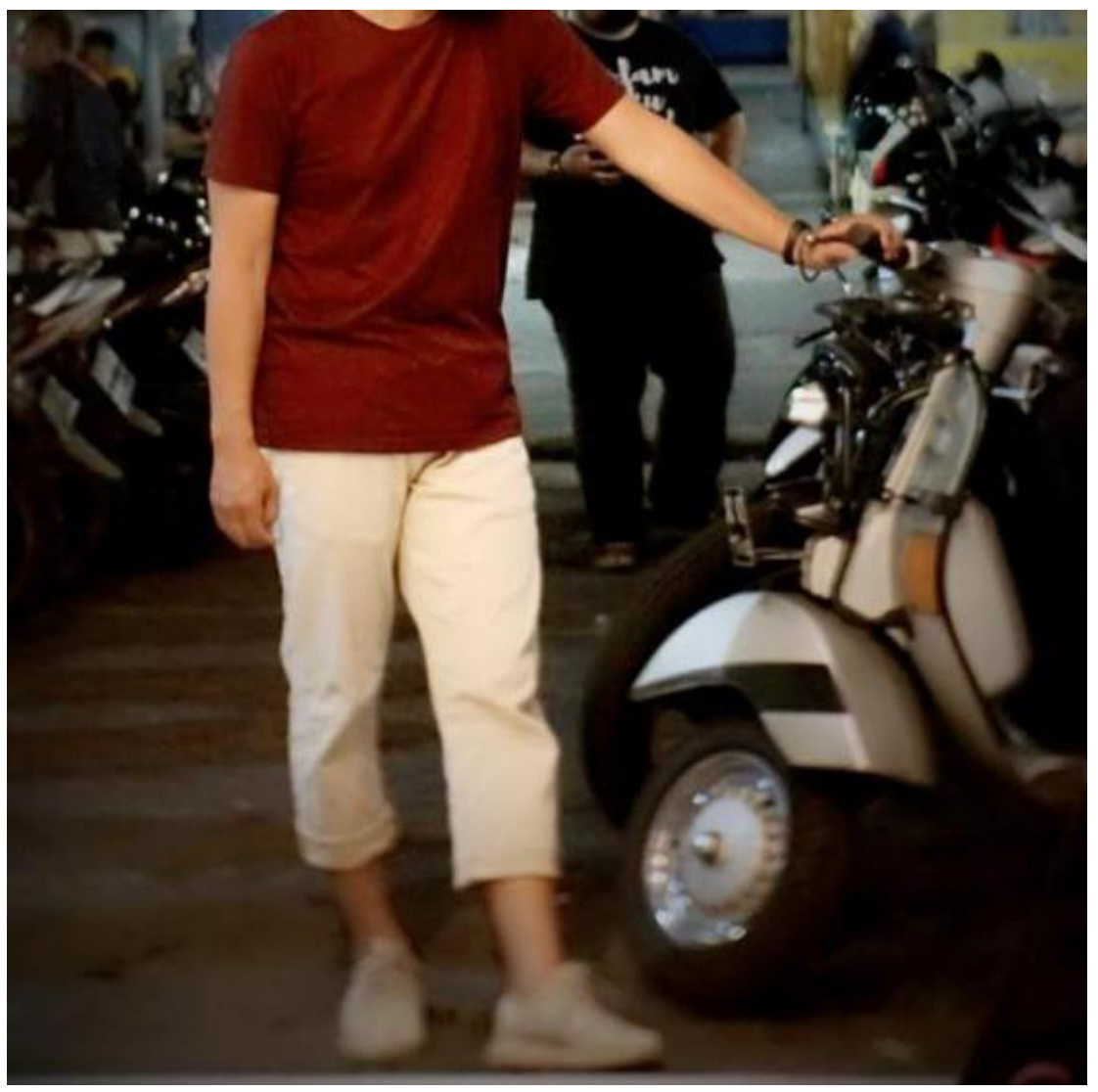

Gambar 1 Gaya berpakaian anggota komunitas TM

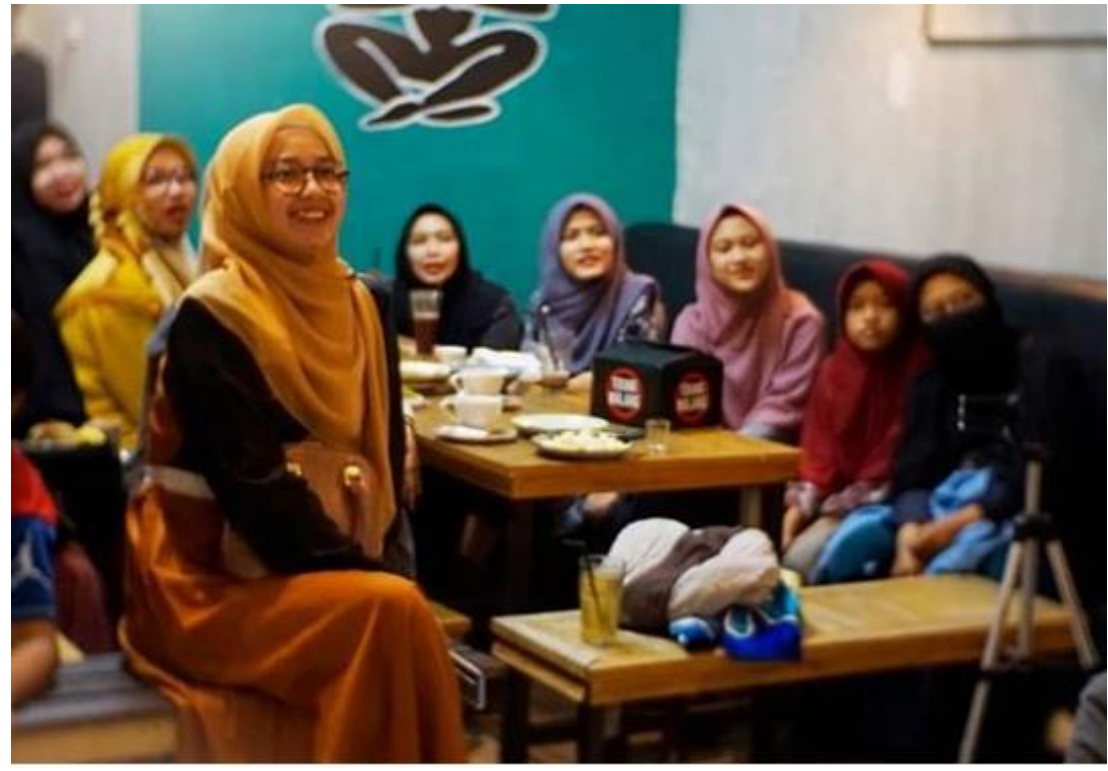

Gambar 2 Gaya berpakaian perempuan dalam komunitas TM 
Pemilihan fashion (pakaian) yang dilakukan oleh TM tentunya juga dilandaskan pada rasionalitas mereka. Rasionalitas tersebut bekerja mengingat target utama mereka adalah generasi muda dan pelaku industri ekonomi milenial. Maka gaya pakaian tersebut dipilih agar sasaran mereka tidak enggan untuk hadir dalam kegiatan yang dilakukan. Komunitas TM menciptakan kekhasan yang berbeda dari stigma umum bahwa hijrah itu kaku dan cenderung mudah untuk mengkafirkan orang lain. Namun di sini sebenarnya letak sisi persuasif tersebut. Melalui simbol pakaian yang jauh dari kesan kaku dan sangat 'islami' mereka berusaha meciptakan 'ruang bersama' yang dapat diisi oleh siapapun dengan latar belakang individu yang berbeda-beda. Hal ini yang kemudian menjadi daya tawar komunitas TM untuk menjadi 'berbeda' (distinction) dari komunitas lainnya. Mereka menciptakan standar baru dengan memadukan tren fashion saat ini dengan kaidah Islam. Misal, bagi Pria, diperbolehkan untuk berpakaian kasual seperti memakai celana jeans, menggunakan kaos, topi (tanpa peci atau atribut islam lainnya) seperti gambar 1, namun harus tetap memelihara jenggot dan celana cingkrang seperti yang dianjurkan Nabi Muhammad. Bagi wanita, tidak diwajibkan untuk bercadar dan berkerudung syar'i, anjuran utama hanya pada menutup aurat. Artinya, bagi wanita pun tidak menjadi masalah jika menggunakan celana jeans dan kaos, karena yang terpenting adalah tetap menutup auratnya. Standar-standar tersebut yang pada akhirnya mengatur praktik berpakaian mereka dan menjadikan hal tersebut sebagai sebuah cara untuk mengkader massa. Hal ini sempat dibicarakan oleh seorang informan yang mengatakan bahwa:

Saya berhijrah, ya memang saya hijrah. Tapi saya tidak bisa mengaji tidak masalah di sini. Maka dari itu saya nyaman di komunitas ini karena tidak mewajibkan ini itu, ini itu seperti lainnya. Bahkan dalam hal berpakaian mereka tidak mengatur. Lihat saja penampilanku, aku gak bercadar kayak lainnya ya, yang terpenting berkerudung dan menutup aurat. Kita tidak diatur, cuman ya akhirnya menjadi diri sendiri, kalo dakwah ya pakai ini aja toh sasaran kita bukan hanya orang yang sudah paham Islam. (Rahmania, wawancara personal, 21 Juni 2020)

Merujuk pada penjelasan di atas, maka yang terpenting adalah bukan pada bagaimana pakaian mereka, atau bahkan brand yang digemari, melainkan lebih pada fungsi dan peran atas pakaian tersebut yang kemudian menjadi media untuk mengkampanyekan wacana hijrah. Gaya berpakaian untuk berdakwah justru tidak digunakan untuk menyeleksi audiens sesuai dengan representasi kelas mereka, karena tujuan utama mereka adalah mendapat banyak massa dan pengkaderan, maka tampilan tersebut justru merepresentasikan gagasan hijrah yang seperti apa yang mereka usung. Sejalan dengan hal tersebut, Kawamura beranggapan gaya berpakaian tidak lagi menjadi tolak ukur atas representasi kelas, namun telah menjadi sebuah representasi atas suatu ide, gagasan, dan identitas yang diekspresikan (Kawamura, 2005).

Konsumsi mereka terhadap fashion ataupun ide mereka dalam memadukan tren fashion saat ini dengan kaidah islam dipengaruhi oleh selera. Selera didapatkan dari modal sosial yang dimiliki individu (Bourdieu, 1996). Ini berguna untuk menjadi pembeda antara dirinya dengan yang lain. Selera merupakan sebuah konstruksi yang mengatur seperangkat preferensi budaya dan penilaian terhadap estetika (Bourdieu, 1996). Selain modal, habitus juga berperan penting sebagai prinsip penghasil yang mengatur praktik sosial dan berbagai jenis modal. Individu secara tidak sadar menggunakan habitus untuk memilih preferensi, praktik sosial, dan selera. Modal melalui praktik konsumsi budaya dan habitus menciptakan gaya hidup yang menjadi ciri suatu kelompok. Habitus memengaruhi perilaku dan preferensi sosial tertentu.

Peran pakaian memberikan sebuah makna tertentu terhadap diri dan orang lain dalam mendefinisikan identitas. Individu cenderung mendefinisikan dirinya dan orang lain melalui penampilan dan fashion yang dikenakan (Skivko, 2018). Untuk itu, Skivko menyebut fashion sebagai sebuah pola pendefinisian diri serta identitas. Ketika berkaca pada apa yang dipraktikkan oleh komunitas TM, fashion tidak hanya berfungsi untuk menutup aurat, ataupun sebagai perlindungan melainkan juga berfungsi sebagai teknik tubuh dalam memanipulasi identitas diri yang bertujuan untuk mendapatkan kader serta penyebarluasan ideologi hijrah. Dengan kata lain, fashion merupakan salah satu cara dan strategi untuk kaderisasi agar ideologi hijrah dapat tersebarluaskan dengan harapan terjadinya perubahan sosial di masyarakat. 
Fashion juga merupakan bentuk respon atas kondisi sosial yang dianggap tidak sesuai dengan ideologi kelompok tertentu. TM tentunya memiliki ideologi-ideologi tertentu yang didasarkan atas pemahaman terhadap sesuatu. Dalam perjalanannya untuk menyebarluaskan pengetahuan 'hijrah', TM memiliki cara-cara dalam merespon ideologi lainnya yang dianggap bersebrangan atau bahkan melawan ketentuan yang ada dalam Islam. Bagi mereka, kondisi sosial saat ini merupakan kondisi yang sangat liberal, sekuler, dan terpengaruh dengan westernisasi, oleh karena itu salah satu perjuangan mereka untuk tetap berada di jalan yang menurutnya benar adalah melalui gerakangerakan dakwah (Ubay, wawancara personal, 20 Juni 2020). Dalam konteks ini fashion juga dapat dikatakan sebagai hasil atas kompromi antara agama dengan modernitas. Mereka mempergunakan fashion sebagai medium yang dilandaskan pada pemaknaan-pemaknaan tertentu dalam menghadirkan kembali pengetahuan hijrah. Wilson meyakini bahwa fashion merupakan perpanjangan tubuh dan pemikiran atas suatu masyarakat tertentu (Wilson, 2003).

Struktur kognitif dari setiap agen yang terlibat memengaruhi pemilihan strategi. Strategi-strategi tersebut digerakkan sesuai dengan habitus dan modal yang dimiliki di dalam suatu arena. Strategi dibagi menjadi dua macam, yakni (1) strategi reproduksi yang merupakan sekumpulan praktik yang dirancang oleh agen untuk mempertahankan atau meningkatkan modal ke arah masa depan, (2) strategi rekonvensi yang merupakan sejumlah pergerakan agen dalam ruang sosial yang terstruktur dalam dua dimensi, yakni keseluruhan jumlah modal dominan dan terdominasi. Kedua strategi tersebut saling mendukung sejumlah praktik yang dilakukan komunitas TM, baik untuk mempertahankan posisi mereka, hingga cara-cara untuk mengumpulkan dan meningkatkan modal. Sesuai dengan fungsinya, habitus berfungsi dalam menggandakan modal (Bourdieu, 1984).

Maka dapat disimpulkan bahwa fashion digunakan sebagai strategi penempatan diri untuk menggiring persepsi atas kesamaan identitas dan kemudian digunakan secara fungsional sebagai upaya untuk mendekatkan diri dengan target dakwah. Melalui peran tersebut pada akhirnya fashion dikemas sedemikan rupa dan dijadikan sebagai strategi dakwah mereka. Fashion menjadi media dalam aktivisme dakwah. Maka dari itu, fashion juga merupakan bentuk komodifikasi dakwah yang dilakukan oleh komunitas TM. Komunitas TM mempergunakan peran fashion untuk menjaring massa, serta memodifikasi gaya dakwah mereka.

Selanjutnya, peran fashion secara sosial juga dipengaruhi oleh praktik sosial yang dihadirkan oleh agen dalam menciptakan realitas sosial. Peran fashion yang dihadirkan dan pada akhirnya melekat dibalik penggunaan pakaian juga terkait dengan struktur kognitif beserta akumulasi modal yang dimiliki. Secara gamblang, pakaian adalah sebuah presentasi, simbol, dan tampilan yang sebenarnya membawa makna-makna lain dibalik penggunaan atas pakaian itu sendiri. Makna yang berusaha dihadirkan oleh agen melalui pakaian dilandaskan pada habitus, modal serta arena pergulatan. Maka fashion adalah representasi atas makna-makna lain yang dibawa oleh agen untuk menciptakan realitas yang bersumber pada habitus dan modal.

\section{Praktik Sosial Dakwah Melalui Strategi Berpakaian}

Penjabaran diatas cukup memberikan gambaran spesifik, bahwasannya fashion juga merupakan strategi dan medium atas usaha-usaha penyebarluasan pesan, ideologi, dan ajakan untuk sebuah perubahan sosial yang masif. Komunitas TM mempergunakan fashion sebagai alat untuk mendekatkan diri dengan kawanan yang 'berbeda' secara ideologis. Seolah fashion menjadi medium yang secara fungsional bertujuan sebagai alat akulturasi untuk menarik simpati dan kemudian untuk tujuan yang lebih masif yaitu penyebarluasan ideologi melalui praktik dakwah.

Ketika meminjam sudut pandang Bourdieu, pemilihan fashion sebagai strategi untuk menjaring pengikut pada dasarnya dilandasi oleh habitus dan modal yang dimiliki oleh setiap agen dalam komunitas (Bourdieu, 1977). Habitus sebagai buah dari sejarah, menghasilkan praktik-praktik baik individual maupun kolektif sesuai dengan skema yang dikandung sejarah. Dalam artian, bahwa habitus menghasilkan disposisi-disposisi pada kehidupan subjektif agen yang mempengaruhi cara ia berpikir dan menentukan tindakan. Disposisi ini merupakan sebuah sikap maupun kecenderungan dalam mempersepsi dan berpikir yang membuahkan sebuah tindakan di realita social (Haryatmoko, 
2016). Disposisi inilah yang pada akhirnya menentukan bagaimana agen mengkonstruksi realita sosial. Agen dalam komunitas TM kebanyakan adalah seorang pelaku usaha. Sebagai pelaku usaha tentunya ia memiliki kecenderungan-kecenderungan yang mempegaruhinya dalam menentukan strategi bagi keberlangsungan dakwah. Cara berpikirnya sebagai pengusaha yang cenderung pandai membaca peluang bisnis dan tren, ia manfaatkan sebagai salah satu strategi untuk mendapatkan pengikut.

Agen dalam komunitas TM merupakan individu-individu dari berbagai latar belakang. Beberapa dari mereka adalah seorang pengusaha, pelaku UMKM, notaris hingga eks bankir. Dilihat dari pekerjaannya, kita dapat menilai bahwa mereka terbiasa untuk membaca peluang pasar, menganalisis tren yang sedang dominan, hingga terbiasa untuk menentukan strategi bagi keberlangsungan usahanya. Habituasi-habituasi dalam kehidupan pribadinya ini tentunya mempengaruhi bagaimana agen berpartisipasi dalam pengorganisasian komunitasnya. Berdasar wawancara, komunitas TM telah menjadi rumah kedua bagi mereka (Kurnia, wawancara personal, 10 Januari 2020). Dalam komunitas itu, mereka tidak hanya sekedar berbagi atau bertukar pikiran dan pengalaman, melainkan melalui komunitas tersebut mereka juga mendapatkan keuntungan secara ekonomi. Diluar komunitas, mereka adalah seorang pengusaha, namun ketika didalam komunitas mereka juga adalah seorang pendakwah (dai). Peneliti beranggapan bahwa, pengusaha dan pendakwah dalam konteks ini memiliki kemiripan. Mereka sama-sama mencari konsumen untuk membeli produk dagangannya. Logika ini pada dasarnya seperti logika transaksi jual-beli. Maka wajar ketika agen dalam komunitas TM pada akhirnya juga menggunakan strategi-strategi seperti pemasaran hingga menerapkan strategi berpakaian yang disesuaikan dengan sasaran dakwah. Strategi yang identik dengan pemasaran ini membuat para pendakwah harus mengidentifikasi siapa pengikutnya, siapa target dakwahnya, bagaimana ia harus memosisikan diri, hingga cara paling efektif yang dilakukan untuk menjangkau targetnya (Silvia, Effendi, \& Sukmayadi, 2019). Seolah kemampuan tersebut tampak alamiah, namun pada dasarnya hal ini merupakan hasil keterampilan yang menjadi tindakan praktis (tidak harus selalu disadari) atas habituasi-habituasi di masa lalu. Disposisi dan logika semacam ini yang akhirnya ditawarkan oleh mereka. Mengingat persaingan dakwah juga cukup masif, sehingga mereka berusaha mencari strategi terbaru yang tidak dipikirkan oleh komunitas lain. Praktik ini yang dikatakan oleh Bourdieu sebagai hasil atas habitus.

Habitus pada akhirnya menjadi perantara antara individu dan kolektivitas. Ia menjamin kehadiran aktif pengalaman-pengalaman masa lalu yang diletakkan dalam bentuk skema persepsi, pemikiran, dan tindakan (Bourdieu, 1990a). Ketika dikontekstualisasikan, habitus agen sebagai pengusaha memiliki konektivitas dengan bagaimana ia membentuk realitas di kehidupan sosial, yang kemudian diterjemahkan sebagai strategi-strategi dakwah. Tidak terbatas itu, habitus yang mengandung sistem disposisi akan terus direproduksi, ia tahan waktu, dan dapat diwariskan (Bourdieu, 1990b). Habitus yang terus direproduksi akan menghabituasi lingkungan sosial dan habitus tersebut seolah menjadi sebuah identitas dan kepribadian dari agen/komunitas. Ketika komunitas TM terus menghabituasi arena dakwah dengan strategi-strategi tersebut (melalui fashion), maka secara tidak langsung hal tersebut telah menghilangkan stigma masyarakat bahwa hijrah adalah sesuatu yang kaku, melainkan muncul kesan bahwa muslim bisa tetap modis dan mengikuti tren fashion meskpiun sedang berhijrah. Dan bahkan lebih ekstrem hijrah justru dapat dipandang sebagai 'cara baru untuk menjadi fashionable' atau dengan istilah lain 'the new cool'. Kesan yang baik terhadap praktik hijrah, makin memudahkan agen untuk mendapatkan pengikut. Semakin banyak pengikut, maka semakin mudah dan efektif bagi mereka untuk menyebarkan ideologinya.

Salah satu strategi mereka untuk mengkonstruksi fashion melalui dakwah adalah dengan berdakwah di kafe, mall, taman, tempat wisata, dan tempat lainnya selain masjid. Ketika dakwah dilakukan di cafe, maka mereka dapat lebih mudah untuk menentukan pakaian yang digunakan. Hal ini kemudian yang dipikirkan oleh mereka terkait dengan audiensnya. Dakwah di Cafe lebih memudahkan audiens mereka untuk datang ke kajian mereka tanpa harus menggunakan pakaian yang tertutup (seperti ke masjid). Maka melalui konstruksi tersebut komunitas TM dapat lebih leluasa menggunakan strategi pemilihan pakaian untuk disesuaikan dengan segmentasinya. Serangkaian praktik tersebut dapat dikatakan sebagai strategi mereka dalam mengkonstruksi dan menyebarluaskan 
wacana hijrah sesuai dengan versi mereka. Artinya strategi pemilihan fashion juga berkaitan dengan pemilihan tempat dakwah. Hal ini sebagai strategi internal mereka untuk mengesankan bahwa komunitas ini bisa menerima siapa saja dan tidak terkesan kaku.

Selain itu, komunitas ini juga sempat mengadakan acara "Halal Fest" di tahun 2019. Acara tersebut pada dasarnya merupakan acara dakwah yang kemudian dikemas dengan rangkaian acara lain seperti Muslim Fashion \& Hijab Style, Halal Traditional and Modern Food, hingga bedah buku. Acara ini juga menjadi salah satu stratgei untuk mengkonstruksi kesan, dan juga sebagai medium ajakan untuk mereproduksi wacana Islam dan ajakan untuk hijrah.

Strategi yang terus direproduksi, pada akhirnya membentuk identitas komunitas. Identitas tersebut sekaligus menjadi pembeda (distinction) dengan komunitas yang lain. Pembeda tersebut dapat terlihat dari habitus-habitus yang dimiliki setiap agen, serta bagaimana setiap agen menerjemahkannya ke dalam suatu tindakan menurut logika arena pertarungan. Hal ini juga merupakan suatu cara untuk menegaskan identitas mereka bahwa komunitas TM adalah komunitas hijrah yang ramah dan terbuka. Ulasan diatas menyimpulkan suatu premis bahwa individu sebagai agen dipengaruhi oleh habitus, dan di sisi lain individu adalah agen yang aktif untuk membentuk habitus. Agen dalam bertindak tidak seperti mesin yang bergerak apabila ada yang memerintah, melainkan ia adalah individu yang bebas bergerak seturut dengan keinginannya. Namun disatu sisi ia juga terikat dalam struktur kolektif. Sepintas habitus seolah merupakan sesuatu yang alami atau pemberian akan tetapi dia adalah konstruksi (Edkins \& Williams, 2013).

Gagasan Bourdieu pada dasarnya berusaha menjembatani dikotomi antara individu dengan masyarakat, agency dengan struktur. Pemikirannya mengenai dunia sosial mampu menjelaskan mengenai proses-proses yang dilalui untuk menciptakan dunia sosial ataupun perilaku manusia dalam bertindak yang secara tidak sadar dilakukan oleh manusia. Ia melihat bagaimana individu berelasi sehingga membentuk 'praktik'. Praktik pada konsep Bourdieu dipahami sebagai produk dari relasi antara habitus dan ranah dengan melibatkan modal didalamnya. Keberadaan modal menjadi sangat penting bagi agen untuk menguasai ranah sebagai arena pertarungan. Modal sendiri erat kaitannya dengan habitus seseorang, karena sebagian habitus berperan sebagai pengganda modal (Harker, Mahar, \& Wilkes, 2009). Agen menempati posisi masing-masing yang ditentukan oleh dua dimensi, yaitu menurut besarnya modal yang dimiliki, dan kedua sesuai dengan bobot komposisi keseluruhan modal mereka(Bourdieu, 1990b). Artinya pemetaan hubungan kekuasaan dalam suatu ranah didasarkan atas kepemilikan kapital-kapital dan komposisi atas kapital tersebut.

Termasuk komunitas TM juga memiliki modal-modal yang dapat digunakan untuk mempertahankan atau mendominasi komunitas lain. Tentunya, persaingan yang dilakukan oleh tiap komunitas dakwah untuk memperbaiki posisinya tidak hanya sebatas pada penyebaran wacana atau ideologi melainkan didukung juga oleh modal yang dimiliki. Modal dapat dipertukarkan dan diakumulasikan antara satu dengan yang lainnya (Harker et al., 2009). Pertukaran dan akumulasi ini menjadi penting dalam sebuah ranah untuk merebut dan mempertahankan perbedaan dan dominasi. Komunitas TM memiliki modal ekonomi yang kuat. Mengingat pengurus dan anggota adalah pengusaha yang berasal dari kelas sosial menengah dan kelas sosial atas. Modal ekonomi tersebut diakumulasikan dan didukung dengan modal budaya yang kuat melalui pembawaan diri mereka yang tampak agamis, ramah, dan cara berbicara yang santun. Mereka juga memiliki modal pengetahuan yang kuat baik dalam praktik beragama maupun pengetahuan terkait ekonomi. Modal tersebut juga diakumulasikan dengan keterlibatan jaringan pengetahuan dan juga jaringan aktor seperti ustadz Hanan Attaki, ustadz Abu Fida, Felix Siauw, bahkan artis-artis hijrah lainnya. Jaringan ini didapatkan karena komunitas TM memiliki afiliasi dengan TM se Indonesia, mulai dari Jakarta, Jogja, dan Bandung. Jaringan gerakan komunitas ini sebenarnya jaringan gerakan yang ada di setiap kota. Mereka bersama-sama melakukan gerakan ini dengan strategi yang berbeda di tiap kota. Mereka memiliki tujuan yang sama serta pola pengorganisasian yang sama, namun cara mendapatkan massa berbeda yang disesuaikan dengan tipologi masyarakat dari setiap kota (Harker et al., 2009). Artinya ketika diklasifikasikan, komunitas TM dan afiliasinya juga bagian dari gerakan Islam Indonesia yang secara aktif mengajak generasi muda berhijrah melalui aktivisme dakwah. 
Jaringan aktor, pengetahuan, dan jaringan komunitas membuat komunitas TM memiliki modal sosial yang kuat sebagai sumber daya untuk penentuan kedudukan sosial. Modal sosial yang dimiliki tersebut kemudian ditukar menjadi modal simbolik. Modal simbolik turut dikuasai berkat jaringan aktor dan pengetahuan yang dimiliki. Modal simbolik berfungsi untuk melegitimasi keberadaan agen dalam ranah pertarungan. Artinya semakin kuat modal simbolik yang dimiliki, maka semakin besar peluang mereka untuk menjadi dominan.

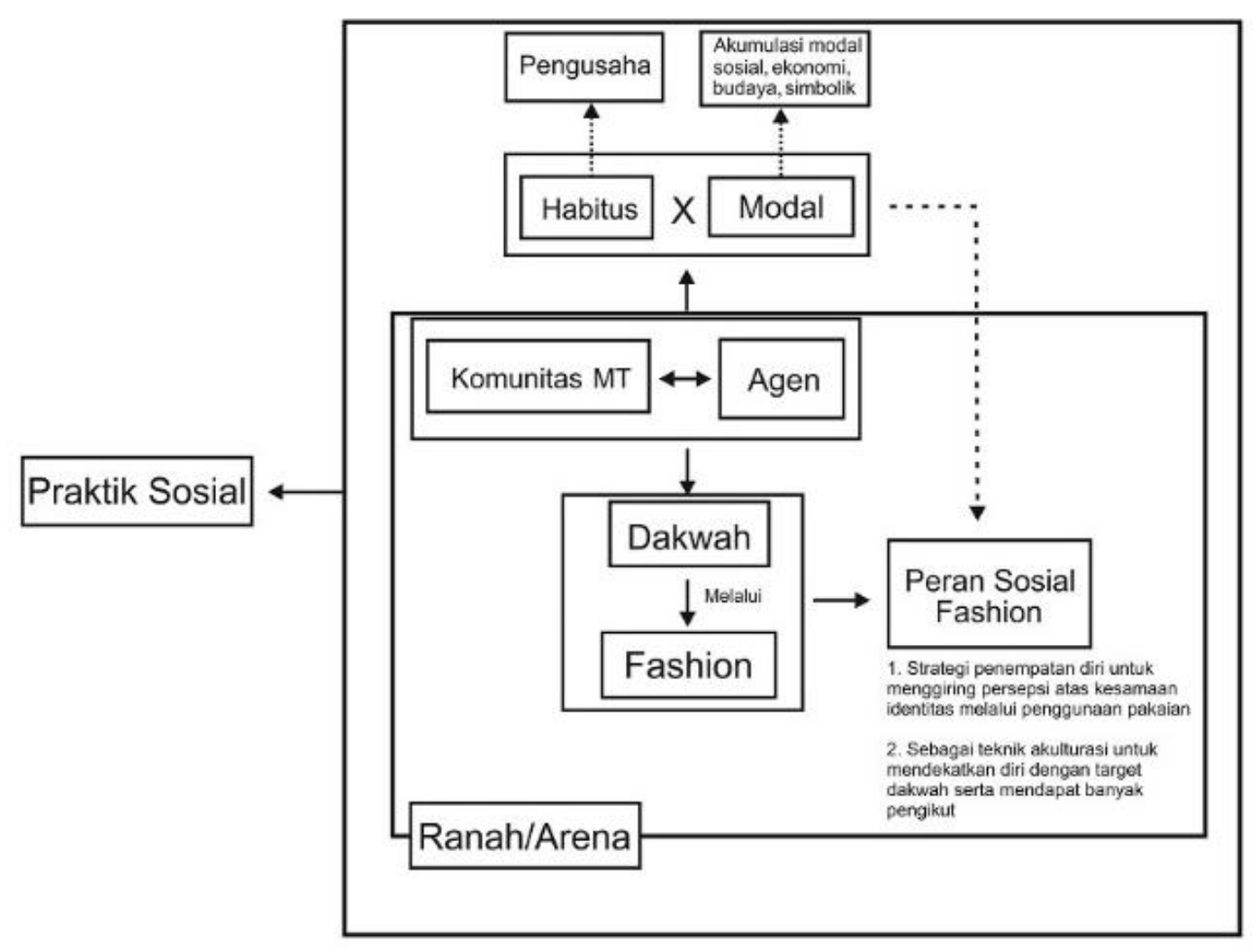

Gambar 3 Skema Analisis

Analisis penelitian ini dapat digambarkan dalam sebuah skema konseptual seperti gambar 2 . Kemunculan praktik sosial dakwah dengan menggunakan strategi berpakaian dilandasi oleh struktur habitus dan struktur modal yang dimiliki oleh agen. Habitus dengan dukungan modal ekonomi, budaya, simbolik, dan sosial yang kuat menjadi landasan penentu praktik sosial yang dilakukan oleh komunitas TM. Menjadi wajar ketika strategi berpakaian dipilih mengingat modal, habitus dan jaringan mereka kebanyakan adalah dari pelaku usaha, artis, hingga ustadz-ustadz kondang. Mereka sangat peka terhadap peluang dan tren yang sedang berkembang saat ini. Hal tersebut kemudian yang memicu rasionalitas mereka untuk melakukan penyesuaian diri melalui pakaian dengan mengkombinasikan tren saat ini dengan kaidah-kaidah dalam Islam. Keberadaan modal dan habitus ini memungkinkan bagi mereka untuk menjadi dominan di ranah pergulatan dakwah. Habitus dan modal yang dimiliki menciptakan strategi dakwah sebagai sarana untuk memenangi suatu ranah. Bagi kelompok yang memiliki modal paling besar maka akan lebih mudah untuk menguasai ranah sehingga mampu menciptakan tindakan-tindakan yang dianggap tepat di dalam ranah tersebut. Strategi yang dihasilkan dari struktur habitus dan modal pada akhirnya juga menjadi ciri khas/identitas dari komunitas TM. Ini penting bagi mereka untuk mempertahankan, mendominasi, dan membedakan posisinya diantara komunitas yang lain. 


\section{Kontribusi Terhadap Wacana Hijrah di Indonesia}

Perkembangan teknologi pada akhirnya juga mengubah praktik beragama muslim. Definisi 'mengubah' pada konteks ini tidak selalu didefinisikan dengan mengganti atau menghilangkan, namun justru berarti menambah ragam baru. Keragaman dalam praktik beragama pada akhirnya membentuk sebuah pola baru, di mana setiap komunitas seolah dituntut untuk 'seirama' dengan perkembangan era dan tren yang sedang berlaku. Pola tersebut mengajak setiap komunitas untuk berlomba saling memberikan daya tawar yang menarik agar audiens berada pada wacana yang sedang mereka usung. Wacana hijrah menjadi topik yang menarik. Ia mewarnai dinamika Islam di Indonesia saat ini. Pada analisis ini, peneliti mendefinisikan hijrah sebagai sebuah konsep baru terkait pengekspresian kesalehan sosial. Ia merupakan sebuah gaya hidup baru yang tuntunanya dilandaskan pada Islam. Untuk mereproduksi wacana hijrah, komunitas hijrah perlu memodifikasi gaya dakwah mereka. Komunitas TM mempraktikkannya melalui pemilihan gaya berpakaian yang dilakukan pada aktivisme dakwah. Pakaian pada konteks ini diposisikan sebagai medium sekaligus 'new way' untuk mendekatkan diri kepada target dakwah. Fashion seolah adalah sebuah strategi, cara, umpan, dan metode untuk menjaring banyak massa.

Yang menarik dalam tulisan ini, praktik fashion dalam aktivisme dakwah merupakan sebuah medium untuk mengkampanyekan gaya hidup dibalik acuan hidup. Fashion yang erat kaitannya dengan gaya hidup, justru menjadi cara baru bagi mereka untuk mengatur dan mengkampanyekan gaya hidup baru sesuai dengan Islam. Artinya, pengorganisasian tersebut justru dilakukan melalui tren gaya hidup yang akhirnya juga melahirkan gaya hidup baru. Kemudian, fashion dalam diskursus hijrah pada akhirnya juga menjadi salah satu instrumen yang digunakan untuk usaha perubahan sosial melalui gaya hidup sesuai syariat Islam.

Tulisan ini juga menelaah lebih jauh bahwa pemilihan fashion sebagai strategi untuk mendapatkan massa dipengaruhi oleh habitus dan modal yang dimiliki. Afiliasi mereka dengan TM se Indonesia dan juga ustadz ternama seperti Hanan Attaki, Felix Siauw tentunya memiliki peranan terhadap penentuan strategi serta pengorganisasin terhadap kesan. Bercermin pada hal tersebut, menggambarkan bahwa saat ini gerakan hijrah di Indonesia memang lebih banyak dipraktikkan melalui cara-cara yang lebih populer serta mengikuti tren. Sehingga tulisan ini dianggap penting dalam diskursus hijrah di Indonesia, mengingat tulisan ini membedah bagaimana strategi-strategi populer tersebut digunakan dan beroperasi untuk menyebarluaskan wacana hijrah.

\section{Simpulan}

Pemilihan dan penggunaan fashion sebagai strategi dakwah oleh komunitas TM bertujuan sebagai strategi penempatan diri untuk menggiring persepsi masyarakat atas kesamaan identitas melalui pakaian. Pemilihan pakaian yang disesuaikan dengan sasaran dakwah ini secara tidak langsung juga bertujuan untuk mendapatkan massa. Fashion pada akhirnya merupakan alat fungsional yang digunakan sebagai teknik akulturasi untuk mendekatkan diri dengan target dakwah. Peran fashion secara sosial juga dipengaruhi oleh praktik sosial yang dihadirkan oleh agen dalam menciptakan realitas sosial. Peran fashion yang dihadirkan dan pada akhirnya melekat dibalik penggunaan pakaian juga terkait dengan struktur kognitif beserta akumulasi modal yang dimiliki. Secara gamblang, pakaian adalah sebuah presentasi, simbol, dan tampilan yang sebenarnya membawa makna-makna lain dibalik penggunaan atas pakaian itu sendiri. Makna yang berusaha dihadirkan oleh agen melalui pakaian dilandaskan pada habitus, modal serta arena pergulatan. Maka fashion adalah representasi atas maknamakna lain yang dibawa oleh agen untuk menciptakan realitas yang bersumber pada habitus dan modal. Pemilihan fashion sebagai strategi untuk memenangkan ranah pada dasarnya dilandasi atas habitus dan modal yang dimiliki oleh agen. Latar belakang mereka sebagai pengusaha dan pelaku UMKM menghabituasi mereka dalam menentukan strategi dakwah, yang kemudian juga didukung dengan akumulasi modal-modal yang mereka miliki, mulai dari modal ekonomi, modal sosial, modal budaya, dan modal simbolik. Keberadaan modal yang kuat, menjadi sesuatu yang berarti bagi mereka 
untuk dapat mempertahankan, memperkuat, dan membedakan komunitasnya dengan yang lain dalam meraih posisi dominan.

\section{Referensi}

Al-Zaman, M. (2020). Religious Communication in Digital Public Sphere. Al-Zaman, M.(2020). Religious Communication in Digital Public Sphere. Jurnal Penelitian, 29-42.

Aspers, P., \& Godart, F. (2013). Sociology of Fashion: Order and Change. Annual Review of Sociology, 39(1), 171-192. https://doi.org/10.1146/annurev-soc-071811-145526

Barendregt, B. (2011). Pop, Politics and Piety: Nasyid Boy band Music in Muslim Southeast Asia (Islam and; A. N. Weintraub, Ed.). London: Routledge.

Berglin, L., Cederwall, S. L., Hallnäs, L., Jönsson, B., Kvaal, A. K., Lundstedt, L., ... Thornquist, C. (2006). Interaction Design Methods in Fashion Design Teaching. The Nordic Textile, 1(1), 26-51.

Bourdieu, P. (1977). Outline of Theory of Practices. London: Cambridge University Press.

Bourdieu, P. (1984). Distinction: A Social Critique of The Judgements of Taste. Harvard Univeristy Press.

Bourdieu, P. (1990a). In Other Words: Essays Towards a Reflexive Sociology. Cambridge: Polity Press.

Bourdieu, P. (1990b). The Logic of Practise. California: Stanford University Press.

Bourdieu, P. (1996). The Rules of Art. California: Standford University Press.

Campbell, H. (2010). When Religion Meets New Media. New York: Routledge.

Casewit, D. S. (1998). Hijra as history and metaphor: A survey of Qur'anic and Hadith sources. Muslim World, 88(2), 105-128.

Cohen, A. P. (1985). The Symbolic Construction of Community. London: Routledge.

Craik, J. (2009). Fashion: The Key Concept. New York: Berg.

Desan, M. H. (2014). Bourdieu, Marx, and Capital: A Critique of the Extension Model. Sage Journals, 31(2), 318-342. https://doi.org/https://doi.org/10.1177/0735275113513265

Edkins, J., \& Williams, N. V. (2013). Teori-teori Kritis Menantang Pandangan Utama Studi Politik International (T. W. Utomo, Ed.). Yogyakarta: Pustaka Pelajar.

Flugel, J. C. (1930). Psychology of Clothes. New York: AMS Press.

Harker, R., Mahar, C., \& Wilkes, C. (2009). (Habitus modal ) + Ranah = Praktik; pengantar paling komprehensif kepada pemikiran Pierre Bourdieu. Yogyakarta: Jalasutra.

Haryatmoko. (2016). Membongkar Rezim Kepastian, Pemikiran Kritis Post- Strukturalis. Yogyakarta: Kanisius.

Heryanto, A. (2015). Identitas dan Kenikmatan: Politik Budaya Layar Indonesia. Jakarta: Gramedia.

Hew, W. W. (2018). The Art of Dakwah: social media, visual persuasion and the Islamist propagation of Felix Siauw. Indonesia and the Malay World, 46(134), 61-79. https://doi.org/10.1080/13639811.2018.1416757

Huang, X. (2019). Understanding Bourdieu - Cultural Capital and Habitus. Hanoi: Canadian Center of Science and Education.

Husein, F., \& Slama, M. (2018). Online piety and its discontent: revisiting Islamic anxieties on Indonesian social media. Indonesia and the Malay World, 46(134), 80-93. https://doi.org/10.1080/13639811.2018.1415056

Jones, C. (2007). Fashion and faith in urban Indonesia. Fashion Theory, 11(2-3), 211-231.

Kawamura, Y. (2005). Fashionology: An Introduction to Fashion Studies. Oxford: Berg.

Kholifah, S. (2014). Gendered continuity and change in Javanese pesantren. Victoria University.

King, D. A. (1991). Culture, Globalization, And The World System. New York: Palgrave.

Kozel, S. (2008). Closer: Performance, Technologies, Phenomenology. Cambridge: MIT Press.

Masud. (1990). The obligation to migrate: The doctrine of hijra in Islamic law (Dale F.Eic). London: Routledge.

Masud, M. K. (1995). 'Modern usage', section of the article 'Da 'wah'The Oxford encyclopedia of the modern Islamic world Vol. 1: Abba-Fami (J. L. Esposito, Ed.). Oxford: Oxford University Press.

Meuleman, J. (2011). Dakwah, Competition for Authority, and Development. Bijdragen Tot de Taal-, Land- En Volkenkunde, 167(2-3), 236-269.

Nuroniyah, W. (2019). Rethinking Hijab in Contemporary Indonesia: A Study of Hijab Community “Tuneeca Lover Community." Wawasan: Jurnal Ilmiah Agama Dan Sosial Budaya, 4(2), 214-221.

Rakhmani, I. (2017). Mainstreaming Islam in Indonesia. New York: Palgrave Macmillan.

Silvia, M., Effendi, R., \& Sukmayadi, V. (2019). Strategi Content Creator Pada Dakwah Di Media Sosial (Studi Kasus pada Akun Instagram @ @pejuang.mahar). In Research Gate. https://doi.org/10.13140/RG.2.2.30224.76804

Singhal, A., Rogers, E. ., \& Brown, J. . (1993). Harnessing the potential of entertainment-education telenovelas. International Communication Gazette, 51(1), 1-18.

Skivko, M. (2018). Fashion in the City and The City in Fashion: Urban Representation in Fashion Magazines. Chair of Urban Studies and Social Research Faculty of Architecture and Urbanism. Bauhaus: University Weimar. 
Van Bruinessen, M. (2002). Genealogies of Islamic radicalism in post-Suharto Indonesia. South East Asia Research, 10(2), 117-154.

Wilson, E. (2003). Adorned in Dreams: Fashion and Modernity. Rutgers University Press.

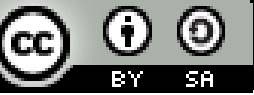

(C) 2020 by the authors. Submitted for possible open access publication under the terms and conditions of the Creative Commons Attribution (CC BY SA) license (https://creativecommons.org/licenses/by-sa/3.0/). 